\title{
Przyznanie się do winy jako warunek zakończenia sprawy w konsensualnym modelu procesu sądowego
}

\begin{abstract}
The aim of the following article is to consider the possibility of accepting the admission of guilt by the defendant as the primary condition for conclusion of the court proceedings in all consensual modes of trial as delineated by the Code of Criminal Procedure. The article contests the validity of the criterion of the seriousness of the act, which has been established by the legislator for the purposes of distinguishing a separate consensual model of court proceedings. At the same time, the article aims to consider whether it would be more reasonable to broaden the possibility of plea bargaining to include all cases, regardless of the seriousness of the act, if the defendant pleads guilty. Moreover, the author considers the prerequisites for sentencing without court proceedings, provided for under Article $335 \S 1$ of the Code of Criminal Procedure, including the assessment of the defendant's own account in the context of all evidence collected in the investigation.
\end{abstract}

Key words: plea bargains, consensualism, guilty plea

\section{Wprowadzenie}

Funkcjonowaniu konsensualizmu $\mathrm{w}$ polskim procesie karnym powszechnym nie można przypisać długiej tradycji, pierwsze bowiem instytucje tego rodzaju wprowadzone zostały wraz z wejściem w życie Kodeksu postępowania karnego z 1997 r. Przyznać jednak trzeba, że pomimo stosunkowo krótkiego czasu ich funkcjonowania, zakorzeniły się one w procesie karnym tak bardzo, że trudno sobie obecnie ten proces bez nich wyobrazić. Zakres zastosowania porozumień procesowych ulegał modyfikacji wraz z kolejnymi nowelizacjami ustawy karnoprocesowej. Nowela marcowa ${ }^{1}$ przewiduje objęcie zakresem zastosowania instytucji dobro-

1 Ustawa z dnia 11 marca 2016 r. o zmianie ustawy kodeks postępowania karnego oraz niektórych innych ustaw, Dz.U. 2016, poz. 437, określana dalej nowelą marcową. 
wolnego poddania się karze ${ }^{2} \mathrm{z}$ art. 387 k.p.k. przestępstw zagrożonych karą do 15 lat pozbawienia wolności ${ }^{3}$, natomiast instytucja skazania bez przeprowadzenia rozprawy w trybie art. 335 k.p.k., po utrzymaniu zmian wprowadzonych nowelą lutową ${ }^{4}$, może znaleźć zastosowanie w każdej sprawie o występek. W rezultacie wskazanych nowelizacji większość spraw może podlegać rozstrzygnięciu w ramach konsensualnego modelu procesu sądowego. Takie „upowszechnienie” wskazanych instytucji prowadzić może do konstatacji, iż konsensualizm, z uwagi na swoje szerokie zastosowanie, nabrał już rangi zasady procesowej ${ }^{5}$. Nasuwać się może jednak wątpliwość, czy nie jest to twierdzenie zbyt pochopne i czy nie należałoby raczej rozpatrywać $\mathrm{w}$ ramach konsensualizmu poszczególnych instytucji prawa karnego procesowego, które w określony sposób funkcjonują na tle naczelnych zasad procesowych. Szczególnie istotna wydaje się również kwestia warunków oraz zakresu zastosowania instytucji konsensualnych w polskim procesie karnym.

\section{Kryterium wyodrębnienia trybu konsensualnego}

Pomimo przyjęcia przyznania się do winy jako podstawowego warunku skierowania do sądu samego wniosku o skazanie bez przeprowadzenia rozprawy (art. $335 \$ 1$ k.p.k.) ustawodawca nie zdecydował się na ujednolicenie warunków zastosowania wszystkich występujących aktualnie $\mathrm{w}$ procesie karnym instytucji konsensualnych. Obecnie podstawowe znaczenie w tym zakresie odgrywa kryterium wagi czynu, pozwalające na zawarcie porozumienia $\mathrm{w}$ sprawach dotyczących określonej części przestępstw. Wydaje się, że w tym miejscu można zastanowić się nad moż-

${ }^{2}$ W niniejszym opracowaniu przyjęto właśnie taką nazwę wskazanej instytucji, należy jednak podkreślić, że w doktrynie procesu karnego brak jest pełnej zgody co do tej kwestii, pojawiają się bowiem głosy co do określenia jej mianem „skróconej rozprawy”, zob. U. WILK: Instytucja skróconej rozprawy jako przykład konsensualnego zakończenia procesu karnego - art. 387 k.p.k. Prok. i Pr. 2005, nr 1, s. 74, czy „procesem karnym skróconym”, zob. P. Rogoziński: Dobrowolne poddanie się przez oskarżonego odpowiedzialności karnej. PiP 2000, nr 9, s. 47 i nast.

3 Tzw. nowela wrześniowa, tj. ustawa z dnia 27 września 2013 r. o zmianie ustawy Kodeks postępowania karnego oraz niektórych innych ustaw, Dz.U. 2013, poz. 1247, rozszerzyła zastosowanie dobrowolnego poddania się karze na wszystkie zbrodnie; regulacja ta obowiązywała od 1 lipca 2015 r. do 15 kwietnia 2016 r.

${ }^{4}$ Ustawa z dnia 20 lutego 2015 r. o zmianie ustawy - Kodeks karny oraz niektórych innych ustaw, Dz.U. 2015, poz. 396, dalej zwana nowelą lutową.

${ }_{5}$ P. WiLIŃsKI: Zasada konsensualizmu $w$ polskim procesie karnym. W: Fiat Iustitia Pereat Mundus. Księga jubileuszowa poświęcona Sędziemu Sądu Najwyższego Stanistawowi Zabłockiemu z okazji 40-lecia pracy zawodowej. Red. P. Hofmański. Warszawa 2014, s. 593 i nast. 
liwością przyjęcia odmiennego kryterium wyodrębnienia postępowania zredukowanego, przewidującego rozstrzygnięcie o przedmiocie procesu $\mathrm{w}$ ramach konsensualnego modelu procesu sądowego. Podkreślenia wymaga fakt, że załatwienie sprawy wskutek zawarcia porozumienia procesowego wiąże się ze znaczną redukcją formalizmu i odejściem od przewidzianego $\mathrm{w}$ trybie zwyczajnym najwyższego standardu gwarancji procesowych. Przyjęte obecnie kryterium wagi czynu, zakreślające zakres zastosowania omawianych instytucji i skutkujące takimi uproszczeniami, skłaniać może do refleksji, że ustawodawca przykłada mniejszą wagę do osiągnięcia sprawiedliwości materialnej w sprawach o mniejszym ciężarze gatunkowym ${ }^{6}$. Tym samym przyjęcie w obecnym stanie prawnym kryterium wagi czynu jako podstawy rozpoznania sprawy w postępowaniu zredukowanym wywoływać może wrażenie, że „osiągnięcie sprawiedliwości materialnej w przypadku przestępstw mniejszej wagi pozostaje w cieniu ekonomicznego aspektu sprawnej realizacji zasady trafnej reakcji i jest w pewnym sensie składane na ołtarzu szybkiego przeprowadzenia procesu karnego"7. Należy mieć na względzie to, że ustawowe zagrożenie nie determinuje stopnia zawiłości określonej sprawy, bowiem z łatwością można sobie wyobrazić sprawę o występek, w której materiał dowodowy jest znacznie bardziej skomplikowany i obszerny niż w sprawie o zbrodnię. Mając powyższe na względzie, wydaje się, że przyjęte przez ustawodawcę kryterium nie jest w pełni zasadne. Można bowiem postawić pytanie, dlaczego ustawodawca pozwala na takie uproszczenia jedynie w sprawach o czyny o niższym zagrożeniu ustawowym, co, jak wyżej wskazano, niekoniecznie świadczyć musi o mniejszym stopniu ich skomplikowania. Wydaje się, że redukcje formalizmu winny iść $\mathrm{w}$ parze $\mathrm{z}$ brakiem wątpliwości co do okoliczności popełnienia czynu, bez względu na to, czy czyn ten stanowi zbrodnię czy występek i ile wynosi przewidziany w ustawie maksymalny wymiar kary. Powyższe rozważania uprawniają do poparcia stanowiska, zgodnie z którym zakres zastosowania instytucji konsensualnych nie powinien być ograniczony do określonej kategorii przestępstw czy też limitowany grożącą za dane przestępstwo karą. Wydaje się, że należałoby umożliwić zastosowanie wskazanych instytucji w sprawach o każde przestępstwo, w tym również o zbrodnie, modyfikując jednak warunki, w jakich skazanie bez przeprowadzenia rozprawy czy w wyniku złożonego wniosku o dobrowolne poddanie się karze mogłoby nastąpić.

Przedstawione rozważania uprawniają do rozpatrzenia możliwości przyjęcia przyznania się do winy jako podstawowego kryterium roz-

${ }^{6}$ J. ZAGRodniK: Model interakcji postępowania przygotowawczego oraz postęowania głównego w procesie karnym. Warszawa 2013, s. 127-129.

7 Ibidem, s. 129. 
poznania sprawy $\mathrm{w}$ trybie konsensualnym. Wskazany warunek przyjęty został w art. $335 \S 1$ k.p.k., natomiast wciąż nie jest to podstawowa przesłanka skazania bez rozprawy w trybie art. 335 § 2 k.p.k. oraz dobrowolnego poddania się karze uregulowanego w art. 387 k.p.k. Niewskazanie takiego wymogu wprost w treści przepisu art. 387 i 338a k.p.k. powoduje wątpliwości co do jego rzeczywistego istnienia, stając się kwestią budzącą $\mathrm{w}$ doktrynie niemałe kontrowersje ${ }^{8}$. Wydaje się, że przyjęcie przyznania się do winy jako podstawowego kryterium decydującego o skierowaniu sprawy do rozpoznania w ramach konsensualnego modelu procesu karnego mogłoby spotkać się z aprobatą, zwłaszcza mając na względzie charakter i cele porozumień procesowych ${ }^{9}$. Nie wolno tracić z pola widzenia tego, że porozumienia przewidziane $\mathrm{w}$ art. 335, 338 a oraz 387 k.p.k. należą do postępowań zredukowanych, których istota zasadza się na ograniczeniu postępowania dowodowego i tym samym przyspieszeniu procedury, co stanowić może argument przemawiający za uznaniem wskazanego postulatu. Niewątpliwie skazanie oskarżonego w wyniku zawartego porozumienia procesowego w sytuacji, gdy nie przyznaje się on do winy lub wprost jej zaprzecza, może budzić poważne zastrzeżenia. Stosowanie instytucji konsensualnych, skutkujących znaczną redukcją formalizmu, a tym samym ograniczeniem uprawnień oskarżonego, podczas gdy nie przyznał się on w sposób wyraźny do winy, jest rażąco sprzeczne z ideą sprawiedliwości proceduralnej i nie może być godne zaakceptowania. Wydaje się, że nie należą do rzadkości sytuacje, w których oskarżony, mając na względzie „opłacalność” takiego zachowania i nie widząc dużych szans na uniewinnienie, kieruje wniosek o dobrowolne poddanie się karze, mimo iż otwarcie zaprzecza swojej winie. Pozostawiając na uboczu to, czy faktycznie jest on sprawcą przestępstwa oraz czy wyrok skazujący był słuszny, należy podkreślić, że uwzględnie-

${ }^{8}$ Za możliwością uwzględnienia wniosku o dobrowolne poddanie się karze $\mathrm{w}$ trybie art. 387 k.p.k. pomimo nieprzyznania się do winy przez oskarżonego opowiadają się m.in.: L.K. PAPRzYCKI: Kodeks postępowania karnego. Komentarz Lex. T. I. Warszawa 2013, s. 1108-1109; R.A. STEFAŃSKI: Skazanie bez rozprawy w znowelizowanym kodeksie postępowania karnego. Prok. i Pr. 2003, nr 6, s. 28. Przeciwny pogląd prezentują m.in.: M. ZвRоJEwsка: Dobrowolne poddanie się karze w kodeksie postępowania karnego. Białystok 2002, s. 167; D. ŚwIECKI: Kodeks postępowania karnego. Komentarz. T. I. Warszawa 2015, s. 1303; A. WaŻNy. W: K.T. BoratyŃsKa et al.: Kodeks postępowania karnego. Komentarz. Warszawa 2012, s. 813.

${ }^{9}$ S. Steinborn wskazuje, że podstawowymi funkcjami porozumień procesowych są uproszczenie trybu wydawania wyroku i przyspieszenie postępowania, ułatwienie pokrzywdzonemu uzyskania naprawienia szkody, tj. funkcja kompensacyjna oraz funkcja wygaszenia konfliktu wywołanego przestępstwem, zob. S. STEINBorn: Porozumienia $w$ polskim procesie karnym: skazanie bez rozprawy i dobrowolne poddanie się odpowiedzialności karnej. Kraków 2005, s. 56-61. 
nie takiego wniosku w wypadku niepoczuwania się oskarżonego do winy i braku jego skruchy niewątpliwie nie spotka się z pozytywnym odbiorem społecznym. $Z$ pewnością jednak umocni w społeczeństwie przekonanie, jakoby organy wymiaru sprawiedliwości nie zawsze dążyły do osiągnięcia prawdy materialnej i pociągnięcia do odpowiedzialności osoby winnej popełnienia przestępstwa, a jedynie do szybkiego i „bezproblemowego” zakończenia postępowania. Wydaje się, że również pokrzywdzony nie zawsze będzie usatysfakcjonowany zakończeniem sprawy, jeśli oskarżony jedynie $\mathrm{z}$ wyrachowania, a nie z poczucia winy, zechce dobrowolnie poddać się karze. Wprawdzie zgodnie z art. 343 \$ 2 oraz 387 § 2 k.p.k. wniosek o skazanie bez przeprowadzenia rozprawy czy dobrowolne poddanie się karze uwzględnione być mogą jedynie wówczas, gdy nie sprzeciwi się temu pokrzywdzony, należy mieć jednak na uwadze, że nie zawsze będzie on chciał się temu wnioskowi przeciwstawić, mając w perspektywie konieczność uczestniczenia w długim i wyczerpującym procesie sądowym. Można zatem wyobrazić sobie sytuację, w której postępowanie karne zostało zakończone $\mathrm{w}$ ramach jednej $\mathrm{z}$ instytucji konsensualnych przy jednoczesnym poczuciu, czy to ze strony pokrzywdzonego, czy sprawcy, że sprawiedliwości nie stało się zadość.

Z pewnością również warunek niebudzących wątpliwości okoliczności popełnienia przestępstwa nie zawsze może być spełniony, gdy oskarżony neguje swoje sprawstwo. Należałoby zatem postulować przyjęcie przez ustawodawcę warunku przyznania się do winy również $\mathrm{w}$ przypadku pozostałych porozumień karnoprocesowych, tj. dobrowolnego poddania się karze przewidzianego $\mathrm{w}$ art. 338a oraz 387 k.p.k. Pojawia się jednak pytanie, jak ukształtowana musiałaby zostać relacja pomiędzy postępowaniem przygotowawczym a postępowaniem jurysdykcyjnym, by model konsensualnego postępowania sądowego w zaproponowanym kształcie umożliwiał pełne osiągnięcie sprawiedliwości materialnej oraz proceduralnej. Dla pełniejszego przedstawienia takiej koncepcji nieodzowne wydaje się zaprezentowanie podstawowych możliwości skonstruowania warunków niezbędnych do zawarcia porozumienia procesowego, zdając sobie sprawę z konieczności znacznego uproszczenia problemu dla potrzeb niniejszego opracowania. W zakresie ukształtowania modelu postępowania konsensualnego z uwagi na kryterium obszerności materiału dowodowego, pozwalającego na rozpoznanie sprawy w tym trybie i stanowiącego podstawę wydanego wyroku, można zatem wyobrazić sobie trzy podstawowe rozwiązania.

1) Po pierwsze, przyjąć można, że rozpoznanie sprawy w trybie konsensualnym byłoby możliwe pomimo braku wyraźnego przyznania się oskarżonego do winy, a podstawę wydanego wyroku stanowiłyby dowody zebrane $\mathrm{w}$ postępowaniu przygotowawczym, jednak z uwagi 
na cel trybów konsensualnych, jakim jest przyspieszenie postępowania, niezasadne byłoby przeprowadzanie $\mathrm{w}$ stadium jurysdykcyjnym kolejnych dowodów w celu zweryfikowania okoliczności ustalonych $\mathrm{w}$ przygotowawczym stadium procesu. Tym samym wyrok skazujący musiałby być oparty jedynie na dowodach zebranych w pierwszym stadium procesu, przy jednoczesnym braku przyznania się przez oskarżonego do winy, co w sposób oczywisty skłania do konkluzji, że niebezpieczeństwo wydania wyroku nieodpowiadającego prawdzie materialnej uległoby diametralnemu zwiększeniu. Taka koncepcja nie wydaje się zatem możliwa do zaakceptowania.

2) Przyjmując odmienne zapatrywanie, można umożliwić rozpoznanie sprawy $\mathrm{w}$ omawianych trybach pomimo nieprzyznania się do winy przez oskarżonego. Aby jednak „wzmocnić” podstawę dowodową wyroku i nie opierać się jedynie na dowodach pochodzących z postępowania przygotowawczego, w stadium jurysdykcyjnym przeprowadzano by kolejne dowody w celu wyjaśnienia okoliczności popełnienia czynu i usunięcia pojawiających się wątpliwości. Wydaje się jednak, że przyjęcie takiego rozwiązania nie prowadziłoby do przyspieszenia postępowania w sprawach mniej zawiłych, co przecież pozostaje jednym z celów trybów konsensualnych. Pojawia się zatem pytanie o zasadność takiego modelu postępowania zredukowanego, które w zasadzie nie różni się zbytnio od postępowania prowadzonego w trybie zwyczajnym.

3) Ostatnia z prezentowanych koncepcji zakłada możliwość rozpoznania sprawy $\mathrm{w}$ trybie konsensualnym jedynie $\mathrm{w}$ przypadku przyznania się przez oskarżonego do winy. Powyższemu warunkowi powinien towarzyszyć wymóg, by wyjaśnienia te nie budziły wątpliwości w świetle okoliczności popełnienia czynu, ustalonych na podstawie dowodów przeprowadzonych $\mathrm{w}$ postępowaniu przygotowawczym. Odmiennie niż $\mathrm{w}$ obecnym uregulowaniu przepisu art. 335 § 1 k.p.k. to pozostałe dowody byłyby „tłem” dla analizy wyjaśnień oskarżonego, którym nie nadano by szczególnego, nadrzędnego znaczenia. Jeśli zatem pojawiłaby się jakakolwiek sprzeczność pomiędzy okolicznościami przytoczonymi przez oskarżonego a tymi wynikającymi z pozostałych dowodów, wydanie wyroku w omawianym trybie stałoby się niemożliwe. Przyjęcie takiego modelu prowadziłoby do wyraźnej dyferencjacji sposobu procedowania $\mathrm{w}$ trybie konsensualnym i w postępowaniu zwyczajnym, przy uwzględnieniu zasadniczej, wielokrotnie wspominanej już funkcji porozumień, polegającej na uproszczeniu i przyspieszeniu postępowania, zwłaszcza w sprawach mniej skomplikowanych. $\mathrm{Z}$ pewnością zakreślenie warunków $\mathrm{w}$ taki sposób prowadziłoby do ograniczenia liczby spraw rozpoznawanych w omawianych trybach, 
jednakże wydaje się, że ilość w tym wypadku nie powinna stanowić kryterium nadrzędnego.

Podkreślić należy, że istniejące ograniczenia formalizmu procesowego przewidziane $\mathrm{w}$ ramach trybów konsensualnych niekoniecznie skłaniać muszą do przyjęcia twierdzenia, jakoby ustalenia faktyczne, stanowiące podstawę wydanego wyroku, nie były udowodnione, a jedynie uprawdopodobnione ${ }^{10}$. Wydaje się, że nawet $\mathrm{w}$ przypadku przyjęcia przyznania się do winy jako warunku wydania wyroku na podstawie zawartego porozumienia powyższy pogląd nie zawsze znajdzie odzwierciedlenie w rzeczywistości ${ }^{11}$. Prawdopodobieństwo wydania wyroku nieodpowiadającego rzeczywistemu stanowi rzeczy wprawdzie może być wyższe $\mathrm{w}$ postępowaniu zredukowanym aniżeli w postępowaniu zwyczajnym, jednakże nie uprawnia to do twierdzenia, że oparcie rozstrzygnięcia jedynie na uprawdopodobnionych, lecz nieudowodnionych ustaleniach faktycznych stanowiłoby $\mathrm{w}$ tych wypadkach regułę. Przyjęcie z góry takiego założenia negowałoby zasadność funkcjonowania porozumień $\mathrm{w}$ systemie prawa karnego procesowego, a to z uwagi na obowiązującą zasadę domniemania niewinności. Biorąc pod uwagę dobrowolność zawarcia porozumienia, przejawiającą się czy to przez wyrażenie zgody na skierowanie przez prokuratora wniosku o skazanie bez przeprowadzenia rozprawy, czy poprzez złożenie wniosku o dobrowolne poddanie się karze, przyjęcie powyżej wskazanego warunku jako podstawowego wydaje się możliwe do obrony. Konieczne staje się jednak zaznaczenie, że w świetle przedstawionego poglądu przyznanie się do winy ma być podstawowym, lecz niejedynym warunkiem rozpoznania sprawy w jednym z trybów konsensualnych. Należy z całą mocą podkreślić, że wskazanie kryterium przyznania się przez oskarżonego do winy nie wiąże się z nadaniem temu środkowi dowodowemu szczególnego, nadrzędnego znaczenia. W zestawieniu z pozostałymi warunkami, tj. tym, by wyjaśnienia były pełne i złożone dobrowolnie oraz by nie budziły wątpliwości w świetle okoliczności popełnienia czynu, koncepcja ta wydaje się możliwa do zaakceptowania.

Nadanie tak znaczącej roli wyjaśnieniom oskarżonego może rodzić obawy, że organy ścigania będą wpływały na podejrzanego (oskarżonego), namawiając go do przyznania się do winy. Jeśli materiał dowodowy zebrany w danej sprawie jest ograniczony lub niejednoznaczny, a wyjaśnie-

10 D. KARCZMARSKA: Zasada prawdy materialnej a konsensualne formy rozstrzygania spraw karnych. W: Zasada prawdy materialnej. Materiaty z konferencji, Krasiczyn 15-16 października 2005. Red. Z. Sobolewski, G. ARTYMiaK. Kraków 2006, s. 115-116; zob. również: R. Кміесік: Posiedzenie sqdu $w$ procesie karnym. Prawnodowodowa problematyka orzekania poza rozprawa. Lublin 1993, s. 41.

${ }^{11}$ Szerzej zob. J. ZAGRODNIK: Model interakcji postępowania przygotowawczego..., s. $131-135$. 
nia oskarżonego przyznającego się do winy mogłyby stanowić podstawę do ich interpretacji, takie ryzyko może być realne, zwłaszcza w trudnych, skomplikowanych sprawach ${ }^{12}$. Wskazane zachowanie organów ścigania jest jednak dopuszczalne, dopóki nie jest niezgodne z prawem, nie polega na składaniu obietnic niemożliwych do spełnienia czy oszukiwaniu co do stanu innych dowodów itd. W takim wypadku powyższe działanie stanowi jedynie „zachętę” dla oskarżonego, będącą wyrazem dążenia do uzyskania większej liczby dowodów oraz wykrycia prawdy, co zresztą jest również korzystne dla sprawcy, który może zyskać chociażby łagodniejszy wymiar kary ${ }^{13}$.

Konieczne staje się również zaznaczenie, że wyjaśnienia oskarżonego przyznającego się winy, choć należy je oceniać z ostrożnością i dużą dozą krytycyzmu ${ }^{14}$, powinny być traktowane jak inne dowody, są zatem przedmiotem swobodnej oceny organu orzekającego. Przyznanie się do winy nie przesądza automatycznie o uznaniu oskarżonego za winnego i obaleniu domniemania niewinności ${ }^{15}$, może to bowiem nastąpić dopiero po uznaniu przez sąd jego winy za udowodnioną. Tym samym złożenie przez oskarżonego wyjaśnien, w których przyznaje się do zarzucanego mu przestępstwa, nie zwalnia organów z poszukiwania dowodów zmierzających do wyjaśnienia sprawy, nie zmienia zatem rozkładu prawnego obowiązku dowodzenia, który w dalszym ciągu obciąża organ prowadzący postępowanie przygotowawcze ${ }^{16}$.

Propozycja przyjęcia przyznania się do winy jako podstawowego warunku skierowania sprawy do rozpoznania w ramach postępowania konsensualnego znalazła już urzeczywistnienie w ramach skazania bez przeprowadzenia rozprawy z art. $335 \S 1$ k.p.k. Zgodnie z brzmieniem nadanym w drodze noweli lutowej art. 335 \$ 1 k.p.k. przewiduje możliwość złożenia przez prokuratora wniosku o skazanie bez przeprowadzenia rozprawy, jeżeli oskarżony przyznaje się do winy, a w świetle jego wyjaśnień okoliczności popełnienia przestępstwa i wina nie budzą wątpliwości. Redakcja przytoczonego przepisu budzi jednak pewne zastrzeżenia. Prima

12 J. JodŁowsкI: Zasada prawdy materialnej $w$ postępowaniu karnym: analiza $w$ perspektywie funkcji prawa karnego. Warszawa 2015, s. 376-377.

${ }_{13}$ Wyrok SA w Krakowie z dnia 5 czerwca 1996 r., II AKa 125/96, KZS 1996, z. 5-6, poz. 68; wyrok SA w Krakowie z dnia 1 czerwca 1995 r., II Akr 74/95, KZS 1995, z. 6, poz. 33.

${ }_{14}$ Wyrok SN z dnia 2 października 1972 r., OSNKW 1973, nr 2-3, poz. 36.

15 W. Wróbel: O dwóch aspektach konstytucyjnej zasady domniemania niewinności. W: Nauki penalne wobec problemów współczesnej przestępczości. Księga jubileuszowa z okazji 70. rocznicy urodzin Profesora Andrzeja Gaberle. Warszawa 2007, s. 333-334.

16 P.K. SowIŃski: Przyznanie się oskarżonego a skrócone formy procedowania. W: Ocena porozumień procesowych $w$ praktyce wymiaru sprawiedliwości. Red. C. KulEsza. Warszawa 2009, s. 113. 
facie, sprawa wydaje się prosta, mianowicie wszelkie wątpliwości sądu co do zgodności ustalonych w postępowaniu faktów z rzeczywistym stanem rzeczy powinny skutkować uniemożliwieniem wydania wyroku w trybie art. $335 \$ 1$ k.p.k. i koniecznością rozpoznania sprawy na zasadach ogólnych. Należy podkreślić, że w brzmieniu nadanym przez nowelę lutową art. $335 \S 1$ k.p.k. stanowi, iż okoliczności popełnienia przestępstwa mają nie budzić wątpliwości w świetle wyjaśnień oskarżonego przyznającego się do winy. O ile uznanie przyznania się do winy za obligatoryjny warunek zawarcia porozumienia zasługuje na aprobatę, o tyle redakcja wskazanego wyżej przepisu pozostawia wątpliwości co do sposobu interpretacji pozostałych dowodów i wynikających zeń okoliczności. Ścisła interpretacja tego przepisu prowadzić może do konkluzji, że pozostałe okoliczności powinny być oceniane przez pryzmat złożonych wyjaśnień, na podstawie których należy wyeliminować towarzyszące im nieścisłości. Tym samym przed złożeniem wyjaśnień takie wątpliwości mogły istnieć, natomiast powinny zostać usunięte $\mathrm{w}$ wyniku przyznania się oskarżonego do winy, co oznacza, iż ustawodawca nadaje temu środkowi dowodowemu rangę szczególnego, koronnego dowodu ${ }^{17}$. Dla porównania wskazać należy, że przed 1 lipca 2015 r. ustawodawca, zarówno w ramach skazania bez przeprowadzenia rozprawy w trybie art. 335 k.p.k., jak i dobrowolnego poddania się karze na podstawie art. 387 k.p.k., posługiwał się warunkiem, by okoliczności popełnienia czynu nie budziły wątpliwości, jednak nie miały one podlegać ocenie przez pryzmat złożonych przez oskarżonego wyjaśnień. W przypadku odmowy ich złożenia ocena tych okoliczności dokonywana była na podstawie innych dowodów ${ }^{18}$. Przed wejściem w życie noweli lutowej w ramach art. 335 k.p.k. możliwe było zaniechanie dalszych czynności dowodowych w postępowaniu przygotowawczym, jeśli „w świetle zebranych dowodów wyjaśnienia podejrzanego nie budzą wątpliwości”, widać zatem wyraźnie, że w wyniku powyższych zmian, utrzymanych nowelą marcową, nastąpiła znaczna zmiana sposobu oceny materiału dowodowego i nadanie wyjaśnieniom oskarżonego szczególnego znaczenia. Często to właśnie one będą decydowały o tym, czy wątpliwości co do okoliczności popełnienia czynu zachodzą czy nie, a jeśli tak, to analiza wyjaśnień oskarżonego prowadzić może do ich całkowitego usunięcia. Zasadnicze znaczenie ma $\mathrm{w}$ omawianym przypadku sposób oceny wątpliwości organu orzekającego, m.in. tło dla ich analizy. Wydaje się jednak, że to pozostałe dowody, jeśli możliwe jest ich uzyskanie, powinny stanowić punkt odniesienia dla analizy wyjaśnień oskarżonego, a nie odwrotnie. Należałoby zatem skłonić się ku odejściu od ścisłej, ję-

17 J. JodŁowski: Zasada prawdy materialnej..., s. 375-376.

${ }^{18}$ Ibidem, s. 376. 
zykowej analizy aktualnie obowiązującego przepisu w stronę wykładni celowościowej i uznać, że wyjaśnienia oskarżonego przyznającego się do winy nie powinny budzić wątpliwości w świetle pozostałych okoliczności sprawy.

\section{Konkluzje}

Charakter porozumień procesowych, ich istota i konstrukcja wymagają wypracowania pewnych kompromisów, czego skutkiem są mniejsze lub większe odchylenia od realizacji niektórych zasad procesowych. Doskonałym przykładem może być zasada bezpośredniości, której realizacja $\mathrm{w}$ sposób niewątpliwy podlega diametralnemu ograniczeniu w przypadku wniesienia wniosku o skazanie bez przeprowadzenia rozprawy lub dobrowolne poddanie się karze. W tym wypadku realizacja tej zasady poświęcana jest na rzecz przyspieszenia i uproszczenia postępowania karnego ${ }^{19}$. Wydaje się, że na aprobatę zasługuje propozycja, by uczynić wyjaśnienia oskarżonego przyznającego się do winy podstawą dla rozpoznania sprawy $w$ trybach konsensualnych. Zdając sobie sprawę z kontrowersyjności takiego twierdzenia, podkreślić jeszcze raz należy, że rozwiązanie takie z pewnością nie stanowiłoby powrotu do modelu inkwizycyjnego, w którym naczelną zasadę stanowiła paremia „confessio es regina probationum". Przeciwnie, uzasadnione wydaje się twierdzenie, że przyjęcie takiego modelu postępowania konsensualnego stanowiłoby odpowiedź na wyzwania stojące przed współczesnym procesem karnym. Zadając pytanie, czy instytucje porozumień procesowych pozwalają na dotarcie $\mathrm{w}$ procesie karnym do prawdy, być może należałoby oczekiwać odpowiedzi twierdzącej, zastrzegając przy tym jednak, że wskazane regulacje zmuszają do spojrzenia na pojęcie prawdy z innej perspektywy, być może nawet przyjmując odmienną jej definicję.

\section{Bibliografia}

\section{Literatura}

BoratyŃsKa K.T. et al.: Kodeks postępowania karnego. Komentarz. Warszawa 2012. JoDŁOWsкI J.: Zasada prawdy materialnej $w$ postępowaniu karnym: analiza $w$ perspektywie funkcji prawa karnego. Warszawa 2015.

KARCZMARSKA D.: Zasada prawdy materialnej a konsensualne formy rozstrzygania spraw karnych. W: Zasada prawdy materialnej. Materiaty z konferencji,

19 H. Paluszkiewicz. W: System Prawa Karnego Procesowego. Zasady procesu karnego.

T. III. Cz. 2. Red. P. WilińsKi. Warszawa 2014, s. 1102. 
Krasiczyn 15-16 października 2005. Red. Z. SobolewsKi, G. ArTymiaK. Kraków 2006.

KMIECIK R.: Posiedzenie sqadu w procesie karnym. Prawnodowodowa problematyka orzekania poza rozprawa. Lublin 1993.

PAPRZYCKI L.K.: Kodeks postępowania karnego. Komentarz Lex. T. I. Warszawa 2013.

RogozIŃski P.: Dobrowolne poddanie się przez oskarżonego odpowiedzialności karnej. PiP 2000, nr 9.

SowiŃski P.K.: Przyznanie się oskarżonego a skrócone formy procedowania. W: Ocena porozumień procesowych $w$ praktyce wymiaru sprawiedliwości. Red. C. KulEszA. Warszawa 2009.

STEFAŃSKI R.A.: Skazanie bez rozprawy $w$ znowelizowanym kodeksie postępowania karnego. Prok. i Pr. 2003, nr 6.

STEINBORN S.: Porozumienia $w$ polskim procesie karnym: skazanie bez rozprawy i dobrowolne poddanie się odpowiedzialności karnej. Kraków 2005.

System Prawa Karnego Procesowego. Zasady procesu karnego. T. III. Cz. 2. Red. P. WiLIŃsKI. Warszawa 2014.

ŚwIECKI D.: Kodeks postępowania karnego. Komentarz. T. I. Warszawa 2015.

WilińsKi P.: Zasada konsensualizmu $w$ polskim procesie karnym. W: Fiat Iustitia Pereat Mundus. Księga jubileuszowa poświęcona Sędziemu Sądu Najwyższego Stanisławowi Zabłockiemu z okazji 40-lecia pracy zawodowej. Red. P. HofMAŃsKI. Warszawa 2014.

WILK U.: Instytucja skróconej rozprawy jako przykład konsensualnego zakończenia procesu karnego - art. 387 k.p.k. Prok. i Pr. 2005, nr 1.

Wróbel W.: O dwóch aspektach konstytucyjnej zasady domniemania niewinności. W: Nauki penalne wobec problemów współczesnej przestępczości. Księga jubileuszowa z okazji 70. rocznicy urodzin Profesora Andrzeja Gaberle. Warszawa 2007.

ZAGRODNIK J.: Model interakcji postępowania przygotowawczego oraz postępowania głównego $w$ procesie karnym. Warszawa 2013.

ZвRoJewsKa M.: Dobrowolne poddanie się karze $w$ kodeksie postępowania karnego. Białystok 2002.

\section{Orzecznictwo}

Wyrok SN z dnia 2 października 1972 r. OSNKW 1973, nr 2-3, poz. 36.

Wyrok SA w Krakowie z dnia 1 czerwca 1995 r., II Akr 74/95. KZS 1995, z. 6, poz. 33.

Wyrok SA w Krakowie z dnia 5 czerwca 1996 r., II AKa 125/96. KZS 1996, z. 5-6, poz. 68. 